WORKING PAPER \#533

PRINCETON UNIVERSITY

INDUSTRIAL RELATIONS SECTION

SEPTEMBER 2008

http://www.irs.princeton.edu/pubs/pdfs/533.pdf

\title{
What Makes a Homegrown Terrorist? Human Capital and Participation in Domestic Islamic Terrorist Groups in the U.S.A.
}

\author{
Alan B. Krueger* \\ Princeton University and NBER
}

First Draft: June 18, 2008

This Draft: August 13, 2008

\begin{abstract}
This paper compares the characteristics of 63 alleged homegrown Islamic terrorists in the U.S.A. to a representative sample of $1,000+$ Muslim Americans. The alleged terrorists have about average level of education. Those with higher education were judged closer to succeeding.
\end{abstract}

JEL Codes: H56, J24

Keywords: terrorism; homegrown terrorism; human capital

* Alan B. Krueger, Woodrow Wilson School, Princeton University, Princeton, NJ, 08544, (phone) 609-258-4046; (fax) 609-258-2907; akrueger@ princeton.edu. 


\section{Introduction}

Understanding participation in terrorism can be thought of an application of the economics of occupational choice. Several studies have found that people who carry out terrorist attacks tend to be better educated and more advantaged than members of the population from which they are drawn (Russell and Miller, 1983, Krueger and Maleckova, 2003, Berrebi, 2008, Sageman, 2004). This research has focused on terrorists who operated outside the U.S. In addition, most of the available research is limited to individuals who actually succeeded in carrying out terrorist acts. Benmelech and Berrebi (2007) find that failed suicide bombers in Israel tend to have less human capital than successful suicide bombers, and they interpret this evidence as consistent with a Roy-type of assignment model. If this tendency holds more generally, studies that are restricted to terrorists who succeeded in carrying out attacks would be biased in the direction of finding more skilled terrorists due to sample selection. This paper attempts to overcome both of these limitations by contrasting the backgrounds of individuals who allegedly joined homegrown Islamic terrorist cells in the U.S. with other Muslims residing in the U.S.

Specifically, we attempted to track down the backgrounds of all those involved in homegrown Islamic terrorist plots since the first World Trade Center attack in 1993. To be considered a homegrown terrorist plot, the plot had to have been conceived in the U.S. and to have had substantial involvement of U.S. residents. Thus the first attack on the World Trade Center is included, but the second one is not, because the first attack involved substantial participation of residents while the second attack was planned abroad and carried out by individuals who came to the U.S. for the specific purpose of 
carrying out the attack. Other plots in the sample include the Fort Dix plot, the Brooklyn Bridge plot, the Columbus Shopping Mall plot, the Toledo plot, and groups such as the Buffalo Six and Virginia Jihad. Fortunately, most of these plots never advanced very far. The sample includes 63 individuals who were indicted or convicted for involvement in terrorist activities. We compare these individuals to a representative sample of American Muslims from 2007. The data are described in detail in the next section.

Section 3 compares the characteristics of alleged domestic Islamic terrorists with those of the population of Muslims residing in the U.S. The alleged terrorists are somewhat better educated and younger, on average, than the general population of Muslim Americans. This profile is similar to what has been found for terrorists more generally (Krueger, 2007). The alleged domestic terrorists are less likely to be American citizens than other Muslims living in the U.S. and slightly less likely to be converts to Islam. Lastly, we find that alleged domestic terrorists who had completed more schooling were closer to carrying out terrorist plots.

\section{Data}

\section{A. Homegrown Islamic Terrorists}

Data were assembled from several sources. As a starting point, the Homeland Security Administration provided the author with an unofficial list of domestic Islamic terrorist groups and plots, which consisted of links to each group or plot in Wikipedia. This source was supplemented with information on the identity of alleged terrorists from 
Leiken (2006) and the FBI's terrorism prevention reviews from 2002-2005 (available from www.fbi.gov/publications/terror/ terrorism2002_2005.htm). ${ }^{1}$

Once individuals' names were identified, information on their country of birth, citizenship status, educational attainment, occupation, age (at the time they became involved in their alleged terrorist activity), and religious background was assembled from searching newspaper articles, Google searches, Lexis Nexis's scholastic service, legal documents and other unclassified sources. ${ }^{2}$ Data were generally available for age, citizenship status, and country of birth. Education and occupational status were more difficult to obtain, but often available from local newspapers.

The term homegrown terrorist should be taken with a grain of salt. Although all of the 63 individuals in the sample have been charged with terrorist activities, one could question whether some were serious plotters or instead were entrapped by overly zealous law enforcement officials. In addition, our definition of homegrown includes a plot that targeted Canada and one that originated from Canada. Nevertheless, this dataset represents the first attempt to systematically study the backgrounds of the individuals drawn into homegrown Islamic terrorist cells in the United States.

\section{B. Data on American Muslims}

The backgrounds of homegrown terrorists are compared with those of a representative sample of 1,050 Muslims living in the U.S.A. who were surveyed by the

\footnotetext{
${ }^{1}$ The individuals in the sample were allegedly involved in the first World Trade Center bombing, the Fort Dix plot, the Brooklyn Bridge plot, the Columbus Shopping Mall plot, the Toledo plot, the dirty bomb plot, the Millenium bombing plot, or members of groups including the Buffalo Six, the Virginia Jihad, the Jam'iyyat Ul-Islam Is-Saheeh (JIS prison Islam), the Houston Taliban, the Portland Seven, and a smattering of other individuals, such as financiers and alleged al-Qaeda operatives.

${ }^{2}$ My research assistant John Ezekowitz carried out these searches.
} 
Pew Research Center. ${ }^{3}$ Individuals age 18 and older were interviewed from January 24 to April 30 of 2007. The interview lasted around 30 minutes and was conducted in four languages. Respondents were paid $\$ 50$ for the participation. Identifying a representative sample of a relatively small group such as Muslims in the U.S.A. is a difficult task, and the survey involved a complex sampling design that is described in Pew Research Center (2007). Random digit dialing and a sample of individuals with names that are common among Muslims were used to identify the sample.

Sample weights were created by Pew to make the weighted sample representative of the population. The sample weights are used in all tabulations of the Pew data. The sum of the weights approximately equals the total number of Muslims age 18 and older in the U.S. population. (The mean weight per observation was 1107 and the lowest was 65 .) The data on homegrown terrorists is self-weighting, as, in principle, it is the universe of homegrown Islamic terrorists in the period under study. Consequently, when the two samples are pooled together the homegrown terrorists are each assigned a weight of 1. The homegrown terrorists represented .005 percent of the weighted sample of Muslims.

\section{Results}

Table 1 presents means of the two samples. Because the homegrown terrorists are all males, the Pew sample of American Muslims is tabulated for men and women combined and separately for men. In many respects, the profile of the alleged homegrown terrorists is similar to the profiles of terrorists more generally (see Krueger, 2007 for a survey of the backgrounds of members of various terrorist groups). The

\footnotetext{
${ }^{3}$ The data can be downloaded from the Pew Research Center website at http://pewsocialtrends.org/downloads/. I thank Greg Smith for answering questions about the data set and Doug Mills for programming assistance.
} 
homegrown terrorists were notably younger than the population, for example. All of the terrorists were between age 18 and 46 . The average years of schooling of the homegrown terrorists is about a year greater than that of all Muslims living in the U.S., although the difference is not statistically significant.

\section{<TABLE 1 NEAR HERE >}

Figure 1 compares the education distribution of the homegrown terrorists and all Muslims living in America. The homegrown terrorists are decidedly clustered in the middle of the education distribution, in the "some college" and college range. They are underrepresented in the high school and below and post college ranks. For those for whose occupation we could track down, the homegrown terrorists were primarily in middle-class and lower-middle-class jobs. As best we can tell, the homegrown terrorists were no more likely to be idle - defined as neither working nor attending school -- than the population of Muslim Americans. If the sample of American Muslims is limited to men, however, only 27 percent are idle, compared with 35 percent of the alleged homegrown terrorists, but this gap could easily have occurred by chance $(\mathrm{p}=0.29)$.

Compared with the population of American Muslims, the homegrown terrorists are less likely to be U.S. citizens. The homegrown terrorists were slightly more likely to have been born in the U.S. than other Muslims living in the U.S. The Arab region is over represented among the birthplace of homegrown terrorists and "other regions" (primarily Iran) are underrepresented. Just over 20 percent of the homegrown terrorists were in the U.S. illegally, either because they entered the country illegally or because they overstayed a visa. Comparable figures are not available for the population of American Muslims. 


\section{<FIGURE 1 NEAR HERE>}

Table 2 presents probit estimates of the effect of various variables on the likelihood that an American Muslim is charged as being a homegrown terrorist. (The coefficients are scaled to represent marginal effects on the probability of participation using the dprobit command in Stata). The first two columns present results for men and women pooled together, and the last two columns present estimates just for men because all of the alleged terrorists are men. In both samples, education is positively associated with the likelihood of being charged as a terrorist, despite the fact that the sample of homegrown terrorists consists overwhelmingly of individuals who never managed to carry out a terrorist attack. The model in column (4) implies that an additional year of education raises the likelihood that a male will become an alleged terrorist by 4 percent. ${ }^{4}$

\section{<TABLE 2 NEAR HERE>}

Holding other variables in the model constant, younger individuals are more likely to become involved in terrorist activities, a finding that is pervasive in the literature. Benjamin (2007) provides anecdotal evidence that a large number of jihadists are converts to Islam. He includes Jose Padillo, who is part of the sample analyzed here, as an example. Contrary to the presumption that the zeal of converts leads them to be drawn to terrorism, we do not find evidence that converts to Islam are more likely to be among the alleged homegrown terrorists.

Citizens are less likely to become involved in domestic terrorism than are noncitizens. This finding is seemingly inconsistent with Butcher and Piehl's (2007) finding that immigrants are much less likely to be incarcerated than are native born

\footnotetext{
${ }^{4}$ Bear in mind that this semi-elasticity is calculated from a very low base, as only one in 24,000 American Muslims is ever charged with being a homegrown terrorist.
} 
Americans. Country of birth also has some predictive power. Perhaps most striking is the finding that none of those charged with involvement in Islamic terrorism in the U.S. are from Iran despite the large number of Iranian-born Muslims in American; this discrepancy accounts for the negative coefficient on the "other region" dummy variable in the probit equations.

The low pseudo R-squares indicate the difficulty of profiling of homegrown terrorists based on their personal characteristics. Only 6 to 8 percent of the variability in the likelihood of participation in domestic terrorism can be accounted for by personal characteristics.

The final empirical issue considered here is whether more highly educated terrorists were closer to succeeding than less highly educated terrorists. To do this, we assigned a score from 0 to 5 indicating how close the groups were to executing their plan. For example, members of the Buffalo Six were assigned a 0 because it is not clear from the public record whether they were actually planning an attack, the Fort Dix plotters were assigned a 3 because they made some headway toward gaining access to the military base but were careless in their preparation (which led to their capture), and those involved in the first attack on the World Trade Center were assigned a 5 because they executed their plan. Those involved in the second World Trade Center attack, who were also given a rating of 5, were included in this analysis to increase the sample size. These ratings are subjective, but I suspect they reflect the operational effectiveness of the individuals involved.

The correlation between education and the 0-5 operational effectiveness score was $0.24(\mathrm{p}=.06)$. If the $0-5$ effectiveness score is regressed on years of education, convert 
status and age, only education is statistically significant at the 5 percent level. Although not overwhelming evidence, these results are consistent with Benmelech and Berrebi's findings for Palestinian terrorists: higher educated individuals were closer to executing terrorist plots within the U.S. than were less educated individuals.

\section{Discussion}

The hodgepodge of alleged homegrown Islamic terrorists that were studied here do not appear especially deprived. They were about as likely to be idle (neither working nor enrolled in schools) as were other American Muslims, and they had slightly more education than the average American Muslim. These findings are a contrast to what is typically found in studies of participation in criminal behavior more generally.

Because a fairly comprehensive set of participants in terrorist activities were included in the sample, and possibly some who were entrapped or innocuous, the study is able to provide a more complete analysis of the supply of would-be terrorists than is available from studies that are limited to individuals who actually carry out extreme terrorist acts. The fact that many of the terrorist cells were small, autonomous groups composed of volunteers instead of recruits, also suggests that the results reflect supply factors rather than demand factors. Interestingly, the strongest predictors of participation - namely, education and youth -- are similar to those that were found in previous studies that restricted the sample of terrorists to those who successfully carried out terrorist acts. One possible interpretation of the results is that youth and the highly educated tend to hold more extreme views, or are more willing to try to act on extreme views. This may also explain why the profile of terrorists is different from the profile of typical criminals. 
A lack of legitimate opportunities may lead people to crime, while terrorism is more likely motivated by a desire to pursue a political agenda.

The analysis also highlights the difficulty of identifying terrorists from their demographic characteristics. The relatively low R-squares suggest that participation in terrorism has a large unpredictable component. Equally importantly, past patterns may not extend in the future. It is especially difficult to generalize from anecdotal evidence given the wide dispersion in terrorists' backgrounds at a point in time. Converts to Islam, for example, were not over represented among the alleged homegrown terrorists compared with the population of U.S. Muslims, despite some notable cases of converts joining terrorist cells.

Nevertheless, the finding that better educated terrorists were operationally more proficient suggests a benefit from focusing anti-terrorism efforts on individuals who have high levels of education and technical skills. Not only are these individuals more likely to see their plans through to completion if they should join terrorist causes, the positive correlation between education and participation in terrorism suggests that there is a greater supply of potential terrorists among more highly educated individuals. 


\section{References}

Benjamin, Daniel, 2007, “The Convert's Zeal : Radical Islamism Has Become A Magnet for Some of the World's Angriest People," Slate Sept. 7. Available from http://www.slate.com/id/2173561/.

Benmelech, Effraim and Claude Berrebi, 2007, "Human Capital and the Productivity of Suicide Bombers," Journal of Economic Perspectives, 21(3), 223-238.

Berrebi, Claude, forthcoming 2008, "Evidence About the Link Between Education, Poverty and Terrorism Among Palestinians," Peace Economics, Peace Science and Public Policy.

Butcher, Kristin and Anne M. Piehl, 2007, “Why are Immigrants' Incarceration Rates so Low? Evidence o Selective Immigration, Deterrence, and Deportation," NBER Working Paper No. 13229, Cambridge, MA.

Krueger, Alan and Jitka Maleckova, 2003, "Education, Poverty and Terrorism: Is There a Causal Connection?" Journal of Economic Perspectives 17(4), 119-44.

Krueger, Alan, 2007, What Makes a Terrorist: Economics and the Roots of Terrorism (Princeton, NJ: Princeton University Press).

Leiken, Robert S, 2006, Terror Suspect Database, October. Available from http://www.nixoncenter.org/index.cfm?action=showpage\&page=immigratNatlSecur.

Pew Research Center, 2007, Muslim Americans: Middle Class and Mostly Mainstream, Chapter 8, Study Methodology, May 22. Available from http://pewresearch.org/assets/pdf/muslim-americans.pdf.

Russell, Charles and Bowman Miller, 1983, "Profile of a Terrorist," in Perspectives on Terrorism (Wilmington, Del.: Scholarly Resources Inc.), pp. 45-60.

Sagemen, Marc, 204, Understanding Terror Networks (Philadelphia, PA: University of Pennsylvania Press). 
Figure 1: Educational Attainment

Homegrown Islamic Terrorists vs. U.S. Muslim Population

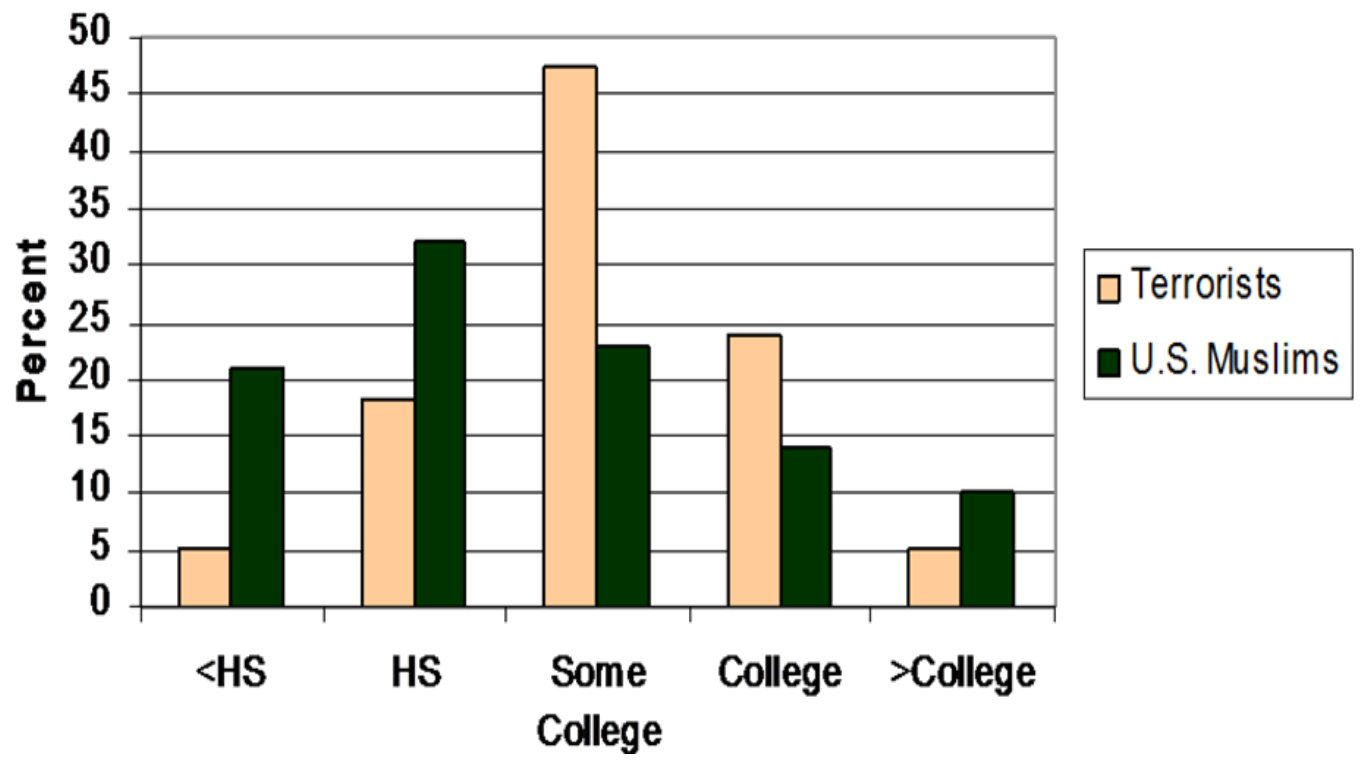

Chi-square test of independence $=126 ; \mathrm{p}$-value $=0.000$ 
Table 1: Sample Averages (standard deviation in parentheses)

\begin{tabular}{|c|c|c|c|}
\hline & \multicolumn{2}{|c|}{ U.S. Muslims } & \multirow{2}{*}{$\begin{array}{l}\text { Homegrown Islamic } \\
\text { Terrorists }\end{array}$} \\
\hline & $\underline{\text { All }}$ & Men & \\
\hline Years of School & $\begin{array}{l}12.94 \\
(3.47)\end{array}$ & $\begin{array}{l}13.02 \\
(3.37)\end{array}$ & $\begin{array}{l}13.77 \\
(2.41)\end{array}$ \\
\hline Age & $\begin{array}{l}38.74 \\
(13.88)\end{array}$ & $\begin{array}{l}38.92 \\
(13.65)\end{array}$ & $\begin{array}{l}27.85 \\
(6.68)\end{array}$ \\
\hline Male & $51.9 \%$ & $100 \%$ & $100 \%$ \\
\hline Idle & $35.6 \%$ & $27.4 \%$ & $34.9 \%$ \\
\hline Convert & $22.8 \%$ & $23.5 \%$ & $13.3 \%$ \\
\hline U.S. Citizen & $75.0 \%$ & $77.5 \%$ & $57.1 \%$ \\
\hline \multicolumn{4}{|l|}{ Born in: } \\
\hline USA & $34.3 \%$ & $37.4 \%$ & $39.7 \%$ \\
\hline Arab Region & $19.0 \%$ & $17.8 \%$ & $36.5 \%$ \\
\hline South Asia & $17.8 \%$ & $17.2 \%$ & $14.3 \%$ \\
\hline Europe & $6.0 \%$ & $7.2 \%$ & $6.5 \%$ \\
\hline Other & $22.9 \%$ & $20.5 \%$ & $3.2 \%$ \\
\hline
\end{tabular}

Notes: Idle is defined as neither working nor attending school. Convert is defined as someone who was not born a Muslim. Other region mainly includes African and Iran. For column (1) sample size is 1,031 for years of schooling, 1,027 for age, 1,048 for convert, and 1,050 for all other variables. For column 2 sample size is 546 for years of schooling, 544 for age, 554 for convert, and 555 for all other variables. For column (3) sample size is 47 for education, 61 for age, and 63 for all other variables. Weights are used for columns (1) and (2). 
Table 2. Probit estimates for likelihood of being charged a homegrown terrorist

\begin{tabular}{|c|c|c|c|c|}
\hline & \multicolumn{2}{|c|}{ Men and Women } & \multicolumn{2}{|c|}{ Men } \\
\hline & (1) & (2) & (3) & (4) \\
\hline \multirow[t]{2}{*}{ Years of Schooling } & $.033^{* *}$ & $.036^{* * *}$ & $.027 * *$ & $.038^{*}$ \\
\hline & $(.011)$ & $\begin{array}{l}(.016) \\
-022 * * *\end{array}$ & $(.012)$ & $\begin{array}{l}(.018) \\
(027 * * *\end{array}$ \\
\hline Age & --- & $\begin{array}{l}-.022 * * * \\
(.004)\end{array}$ & --- & $\begin{array}{l}-.022^{* * * *} \\
(.005)\end{array}$ \\
\hline Convert (1=yes) & --- & $\begin{array}{l}-.013 \\
(.121)\end{array}$ & --- & $\begin{array}{l}-.011 \\
(.147)\end{array}$ \\
\hline Citizen (1=yes) & --- & $\begin{array}{l}-.267 * * \\
(.126)\end{array}$ & --- & $\begin{array}{l}-.368^{* *} \\
(.154)\end{array}$ \\
\hline Idle (1=yes) & --- & $\begin{array}{c}.059 \\
(.102)\end{array}$ & --- & $\begin{array}{l}.264 \\
.121)\end{array}$ \\
\hline \multicolumn{5}{|l|}{ Birth Region: } \\
\hline Arab & $\begin{array}{l}.039 \\
(.090)\end{array}$ & $\begin{array}{l}-.067 \\
(.150)\end{array}$ & $\begin{array}{l}.061 \\
(.099)\end{array}$ & $\begin{array}{l}.031 \\
(.175)\end{array}$ \\
\hline South Asia & $\begin{array}{l}-.114 \\
(.106)\end{array}$ & $\begin{array}{l}-.164 \\
(.147)\end{array}$ & $\begin{array}{l}-.107 \\
(.117)\end{array}$ & $\begin{array}{l}-.118 \\
(.172)\end{array}$ \\
\hline Europe & $\begin{array}{l}-.174 \\
(.185)\end{array}$ & $\begin{array}{l}-.324^{*} \\
(.189)\end{array}$ & $\begin{array}{l}-.215 \\
(.201)\end{array}$ & $\begin{array}{l}-.370 \\
(.234)\end{array}$ \\
\hline Other & $\begin{array}{l}-.607 * * * \\
(.225)\end{array}$ & $\begin{array}{l}-.722 * * * \\
(.255)\end{array}$ & $\begin{array}{l}-.602 * * \\
(.238)\end{array}$ & $\begin{array}{l}-.765^{* *} \\
(.300)\end{array}$ \\
\hline Pseudo R-Square & .021 & .064 & .021 & .082 \\
\hline Chi-Square & 11.7 & 46.0 & 10.6 & 41.4 \\
\hline Sample Size & 1,078 & 1,067 & 593 & 586 \\
\hline
\end{tabular}

Notes: Dependent variable equals 1 for alleged homegrown terrorists and 0 for others. All equations also include a constant. Robust standard errors reported in parentheses. All estimates use sample weights. Base group for birth region is U.S.A.

* Statistically significant at .10 level.

** Statistically significant at .05 level.

*** Statistically significant at .01 level. 